\title{
International financial institutions and human rights: implications for public health

Thomas Stubbs ${ }^{1,2^{*}}$ (D) and Alexander Kentikelenis 3,4 $^{3,4}$

\author{
* Correspondence: ths27@cam.ac.uk \\ ${ }^{1}$ Centre for Business Research, \\ University of Cambridge, \\ Cambridge, UK \\ 2Department of Politics \& \\ International Relations, Royal \\ Holloway, University of London, \\ Egham, UK \\ Full list of author information is \\ available at the end of the article
}

\begin{abstract}
Serving as lender of last resort to countries experiencing unsustainable levels of public debt, international financial institutions have attracted intense controversy over the past decades, exemplified most recently by the popular discontent expressed in Eurozone countries following several rounds of austerity measures. In exchange for access to financial assistance, borrowing countries must settle on a list of often painful policy reforms that are aimed at balancing the budget. This practice has afforded international financial institutions substantial policy influence on governments throughout the world and in a wide array of policy areas of direct bearing on human rights. This article reviews the consequences of policy reforms mandated by international financial institutions on the enjoyment of human rights, focusing on the International Monetary Fund and World Bank. It finds that these reforms undermine the enjoyment of health rights, labour rights, and civil and political rights, all of which have deleterious implications for public health. The evidence suggests that for human rights commitments to be met, a fundamental reorientation of international financial institutions' activities will be necessary.
\end{abstract}

Keywords: Structural adjustment, Human rights, International financial institutions, International Monetary Fund, World Bank

\section{Background}

After the 2007 global financial crisis, several European countries experienced growing public debts and shrinking economic output. Greece was one of several countries that, in 2010, sought the assistance of international financial institutions to finance upcoming debt repayments. The country initially borrowed $€ 110$ billion from the International Monetary Fund (IMF) and Eurozone partners under strict condition that there would be drastic curtailing of government spending. This had deleterious and potentially long-lasting public health implications. Cuts to municipal budgets led to scaling back of mosquito-spraying programmes, resulting in the re-emergence of locally transmitted malaria for the first time in 40 years; public hospital budgets were reduced by $26 \%$, leading to staff overwork, increasing waiting lists, and shortages of medicines and medical equipment; and prevention and treatment programmes for illicit drug use also faced cuts, leading to increases in HIV infections from intravenous drug users [1-3]. In the throes of unprecedented levels of unemployment, welfare services were also cut in Greece, leaving vulnerable groups without access to income and confronted with an overburdened and increasingly pricey health system [4]. In a 
scathing assessment of the policy reforms adopted at the behest of the IMF and Eurozone partners, the United Nations Human Rights Committee concluded that they were in violation of several human rights obligations, including the right to work, health, and social security $[5,6]$.

The experience of Greece is far from unique. International financial institutions (IFIs) - a term collectively referring to the IMF, the World Bank, and regional development banks-condition the provision of loans, grants, and debt relief on the implementation, by the recipient country, of a series of policy reforms. These are typically aimed at making the fiscal and debt situation sustainable, improving competitiveness, and boosting economic growth. Common measures that governments are required to implement include privatisation of public assets, public spending cuts (or 'austerity'), and structural reforms (such as changes to labour market reforms, trade liberalisation, and legal reform). This practice of 'conditionality' affords IFIs substantial policy influence on governments throughout the world, thereby reducing national policy space and undermining national development agendas [7]. The measures also have implications for the enjoyment of human rights, including the right to the highest attainable standard of health.

This article provides an overview of these policies and their impact on the ability of implementing governments to provide basic public services necessary for the realisation of human rights. First, we discuss the mandates, priorities, and lending practices of the two most influential and well-resourced IFIs, the IMF and the World Bank. Subsequently, we review existing debates on the effects of conditionality for the enjoyment of human rights, organised into three thematic dimensions: health, labour, and civil and political rights. We conclude by discussing the broader implications for public health and offer suggestions for revamping IFI lending practices in ways that ensure respect for human rights.

\section{International financial institutions in historical context}

IFIs, such as the IMF, World Bank, and regional development banks, are considered the world's most powerful agents of economic reform [8, 9]. In the past four decades, they have set the fiscal parameters within which public policies-including health-operate in developing countries via their so-called 'structural adjustment' programmes [10]. Among public health advocates, the role of IFIs in affecting population health gained notoriety after the publication of a critical UNICEF report 'Adjustment with a Human Face' [11]. This report found adverse child and maternal health outcomes attributable to the policy reforms promoted by these organisations. Scrutiny surrounding the deleterious effects of IFI activities on the enjoyment of health rights have more recently stepped up following socially regressive programmes in advanced European economies, as the Greek tragedy alluded to in our introduction illustrates.

Serving as lenders of last resort to countries experiencing unsustainable levels of sovereign debt, the IMF and World Bank are among the most influential IFIs [12]. The two organisations possess a similar array of tools for persuading governments to adopt reforms, the best known of which is conditionality: the practice of requiring policy reforms in exchange for access to resources. In conditional lending arrangements with IFIs, policy reforms are outlined in documents specifying timetables for their 
introduction and are assessed on a regular basis. Non-implementation can result in delays in loan disbursements and-ultimately-the suspension of lending altogether. While this process is typically coercive, there are instances where borrowing governments seek out particular policy reforms in order to overcome domestic political opposition or to use IFIs as political scapegoats when establishing unpopular policies [13].

The origins of these organisations can be traced to the Bretton Woods conference in July 1944, which laid the foundations of the post-war economic order [8]. In response to appeals for a system of global financial governance and greater international economic cooperation, the IMF and the International Bank for Reconstruction and Development (later known simply as the World Bank) were established soon after in 1945.

Both organisations have diverged from their original mandate set out at Bretton Woods. The role of the IMF was initially to oversee the exchange rates of member governments and to make financial resources available to member governments facing balance of payment problems [14]. Following the shift to floating exchange rates in 1973, only the second-and most controversial-aspect of the IMF's mandate survived. For its part, the World Bank was established to provide investment capital for post-war reconstruction and economic development. It initially specialised in lending to advanced nations for infrastructural projects, such as ports, railroads, and hydroelectric dams. In response to demands of developing countries for greater financing, however, world leaders set up an additional organisation within the World Bank in 1960, the International Development Association (IDA). This shaped the Bank into a more development-focused organisation, and its mandate expanded to encompass the eradication of global poverty [15].

In meeting these-revised-functions, the two organisations became involved in promoting market-liberalising reforms as part of their lending operations [16]. Through the 1970s and 1980s, the IMF introduced a series of lending programmes targeting structural change, such as the Extended Fund Facility and Structural Adjustment Facility $[17,18]$. Prior to this, reforms attached to IMF loans were largely confined to a series of standard quantifiable targets, such as ceilings to government expenditure and net domestic assets. The new facilities incorporated detailed micro-economic reforms spanning a wide array of policy areas. For its part, the World Bank continued the tradition of providing 'project' lending-for instance, loans to build roads or schools-but, in 1980, also introduced a 'programme' lending facility of its own, the Structural Adjustment Loan [8]. As the 1980s unfolded, the World Bank steadily devoted a larger proportion of its resources to programme lending than to development projects, while the IMF became-for all intents and purposes-a development institute that collaborated with the World Bank [16, 17].

Against a background of debt crises, structural adjustment programmes became ubiquitous in the 1980s, achieving notoriety for requiring low- and middle-income countries to implement free-market policies [8]. Indeed, the term 'structural adjustment' became shorthand for an extensive range of reforms designed to promote fundamental, comprehensive, and enduring overhaul of a borrowing country's policy arrangements [18]. These reforms entailed four key policy pillars: stabilisation, liberalisation, deregulation, and privatisation [19]. Stabilisation refers to fiscal deficit reduction measures-via revenue generation and government expenditure cuts ('austerity') - and to money supply reduction measures, the intent of which is to control inflation, stabilise currencies, and free 
resources to repay external debt. Liberalisation entails the elimination of barriers to trade and the movement of capital in order to facilitate access to international markets and promote foreign direct investment. Deregulation involves the repeal of government rules, regulations, checks, and balances surrounding economic activity-such as industry entry criteria-geared towards abolishing perceived inefficiencies to the functioning of the private sector. Finally, privatisation occasions the selling of state-owned enterprises and natural resources to the private sector, with the aim of improving the economic management of these industries.

For both organisations, the practice of conditionality became a prominent feature of their modus operandi [20], and-by the 1990s-was a staple vehicle for implementing the transition to capitalism in post-communist countries. Securing compliance with these prescriptions was achieved not only through the threat of suspending the loan from borrowing governments but was also encouraged through closer relationships between the IMF, World Bank, various regional development banks, and private creditors [16]. In particular, the various multilateral agencies harmonised and upheld one another's reforms, while the presence of structural adjustment programmes also served as a 'stamp of approval' that could catalyse additional bilateral aid from donor governments-including debt relief-and mobilise financial flows from private international capital [21, 22]. Among the World Bank and regional development banks, policy leverage was also consolidated through greater selectivity in awarding project loans to countries that were compliant with these policies [23].

The IMF and World Bank were widely criticized in subsequent years, especially following their mishandling of the financial crises in Mexico, East Asia, Russia, and Argentina [24, 25]. The organisations promised that painful austerity measures would be justified in the long run by sustained economic growth. Yet, economic growth failed to materialise [26], while the negative consequences for the enjoyment of human rights mounted (discussed below). Faced with disconfirming evidence, the view of the organisations was that structural adjustment programmes had paid insufficient attention to the institutions that allow markets to function, such as laws and judicial systems, but that the underlying market-liberalising impetus was essentially correct [8].

By the early 2000s, in response to extensive criticisms, the IMF and World Bank pledged to strengthen the pro-poor orientation of their programmes and to allow for flexible policy design $[27,28]$. And, in 2009, following the onset of the sovereign debt crises in Europe, structural adjustment programmes of the IMF-in collaboration with European Union institutions-spread to the advanced European economies of Greece, Iceland, Ireland, Portugal, and Cyprus. These programmes were similar to those advocated by the IMF and the World Bank in low- and middle-income countries insofar as they relied on extensive market-liberalising conditionality [29, 30].

\section{Methodological approach}

The main objective of this article is to review the human rights implications of IFIadministered structural adjustment programmes. The review incorporates literature on both developing and advanced nations. We focus on the IMF and the World Bank because they are widely considered the most influential of IFIs [12]. While regional development banks also administer structural adjustment, these bear little point of 
distinction from those of the IMF and World Bank, who often co-finance their loans and share expertise [10].

We conducted a comprehensive search of the literature covering structural adjustment and human rights. First, we searched the websites of the two organisations under review, as well as secondary literature, for information on their human rights stance, related activities in the field, and internal research. Second, we searched two electronic databases (PubMed/MEDLINE and Web of Science) for academic literature. The database search was conducted on February 2017. The search terms included the name of each organisation reviewed or related terminology ('World Bank,' 'Fund, 'IMF, 'structural adjustment', 'polic"', 'reform",', condition"'), as well as human rights-related terms ('right",' health,'labour,' 'labor,' 'democ",' 'social'). Third, we searched for grey literature on the topic using Google and Google Scholar, using an equivalent methodology to the database search outlined above. Fourth, we scanned reference lists of the materials obtained.

The method used to examine the evidence obtained was a narrative synthesis, in order to map proximal and intermediate pathways and identify hypotheses. This approach was appropriate given that data are limited and often haphazardly situated in a large corpus of literature. For example, some studies link the incidence of structural adjustment with the infringement of health and labour rights, whereas other studies document how the latter results in a rise of social protect and instability, leading to violent bouts of repression by the ruling government that amounts to breaches of civil and political rights. We synthesise such findings in order to yield nuanced understandings of the relationships of interest, organised into three human rights thematics: health rights, labour rights, and civil and political rights. These all have broader implications for public health, an issue we return to in the concluding section.

\section{Results}

\section{Health rights}

The realisation of the right to health is codified in the 1966 International Covenant on Economic, Social, and Cultural Rights (ICESCR) and expanded upon in General Comment 14 issued by the UN Committee on Economic, Social and Cultural Rights in 2000 [31]. Rather than a minimalist agenda encompassing health interventions for the most vulnerable, the right to healthcare in ICESCR forms a comprehensive framework of minimal standards and progressive realisation towards the highest attainable standard of health. It offers a legitimate claim to freedoms and entitlements directly related to health, including access to quality and affordable healthcare, as well as indirectly related to health, such as access to food, water, employment, and education [32]. The ICESCR and the General Comment also enshrines these rights as national and international obligations, with the latter related to development cooperation for health [32]. Although the IMF and World Bank have long claimed that they are concerned about the health consequences of their policy advice [7,33], the available evidence suggests that many loan reforms breach these obligations and are detrimental to health outcomes.

IMF and World Bank conditionality directly impacts upon the fulfilment of the right to health by prompting changes to the volume and quality of services provided (like health facilities and medical supplies) [30]. On the one hand, to shelter sensitive expenditure from austerity measures, structural adjustment programmes incorporate 
poverty reduction reforms, typically in the form of priority spending floors that stipulate minimum expenditures on health and education [34-37]. Indeed, the past decade has seen a rapid rise in the inclusion of poverty-reduction reforms [7]. These may in part explain findings from cross-national studies showing that structural adjustment programmes are associated with increases in social spending in sub-Saharan African low-income countries, autocratic countries, and Latin American countries [38-40]. Archival evidence on IMF programmes in West African nations also demonstrates that, in select instances, priority spending floors contributed to increases in budgetary allocations for health [41, 42].

On the other hand, there is compelling evidence to suggest that poverty reduction is accorded subsidiary importance to fiscal reforms. Priority spending targets are most often non-binding reforms that serve as markers for broader progress assessment, but do not automatically suspend a programme if unmet; whereas fiscal deficit targets are binding and automatically suspend the loan [43]. Furthermore, research shows that priority spending targets were observed only about half of the time, even though fiscal deficit reforms were almost always met $[7,41,44]$. As part of an austerity drive, governments may be under pressure to cut social spending in order to meet fiscal deficit targets, which can-in turn-limit the accessibility and affordability of healthcare [7, 10, 18, 41, 45-47].

Several cross-national studies on the effects of structural adjustment on social expenditure suggest that it is associated with decreases in spending in low-income countries outside sub-Saharan Africa and democratic states [38, 39]. A recent study focusing on West African countries also found that each additional IMF condition reduces government health expenditure per capita by $0.25 \%$ [41, 42]. Consequently, countries experience medical supply shortages and replacement of defunded health services with ineffective traditional programmes [10, 18]. Empirical studies assessing the effect of health expenditures or government spending more broadly find a significant and detrimental relationship with infant mortality, under-five mortality and several other health outcomes [10, 48, 49]. The UN Human Rights Council also reports that declines in government spending promoted by IMF programmes in Cyprus, Greece, and Ireland translated into decreases in healthcare staff, reductions in the number of hospital beds, and increases in waiting times for medical procedures [6].

Aside from fiscal reforms, institutional reforms included in structural adjustment programmes can also limit the accessibility and affordability of healthcare. One common measure has been the introduction of user fees for access to healthcare and copayments for medicines or services [50,51]. The rationale for applying such fees was generating additional resources, improving efficiency, and increasing access [52]. In practice, they have undermined the right to health for poor and vulnerable people, both in terms of reducing their use of such services due to prohibitive costs and through impoverishment by the effects of unavoidable health expenses [53-55]. A design simulation model of 20 African countries employing user fees for health concluded that abolition of fees could prevent an estimated 233,000 under-five deaths annually, or 6.3\% of such deaths in these settings [54]. In recent years, the IMF and World Bank policy consensus vis-à-vis low-income countries has moved away from reliance on user fees. Yet, recent structural adjustment programmes in Europe advocated the introduction or increase of user fees or co-payments and made eligibility criteria for subsidised health services more stringent $[1,2,4,6,10,56,57]$. 
Institutional reforms calling for deregulation of the health sector have also enhanced the private sector's role in healthcare provision [58]. While those able to afford it can obtain access to a broader bundle of services, this can be coupled with austerity-driven roll-backs of government health provision to a more limited array of services, or outsourcing to non-governmental organisations who are often less-equipped to provide comprehensive and high-quality health services [18, 46, 59-62]. Furthermore, structural adjustment programmes are linked to health system decentralisation; that is, transferring fiscal and operational responsibilities to the subnational level [41, 44, 58]. In principle, decentralisation can make health systems more responsive to local needs; but-in practice-they often create governance problems and exacerbate local institutional weaknesses that undermine the right to health, especially when managing nationwide disease outbreaks $[41,44,63]$.

Labour-related reforms can also impact upon the right to health in terms of the quantity and quality of the public sector health workforce available, via redundancies, hiring freezes, or wage cuts [41, 44, 64-66]. In West Africa alone, almost half of all years with IMF programmes included reforms stipulating layoffs or caps on publicsector recruitment and limits to the wage bill between 1995 and 2014 [41]. These targets can impede a country's ability to hire, adequately remunerate, or retain health-care professionals, and are linked to medical 'brain-drain' as healthcare workers migrate in search of better employment opportunities [67, 68]. The IMF reports that such wage caps have been discontinued in their programmes [69], but recent evidence shows they are still incorporated into some [7].

Notwithstanding these direct effects of conditionality, the right to health can also be indirectly affected. First, currency devaluations-advocated by the IMF and World Bank to improve the external competitiveness of countries-impede access to imported medicines and medical equipment by raising the price of imports [70]. Second, removal of customs duties reduces trade tax revenues in the short-run, which-unless replaced by alternative sources of revenue-can undermine the fiscal basis of health policy; however, if the economic benefits of openness stimulate economic growth in the mediumterm or if tax revenues are raised elsewhere (e.g. via new consumption taxes or improved tax collection), then greater public revenues could be invested in health [71, 72]. Third, privatisation of state-owned enterprises-designed to raise funds for cashstrapped governments-can result in the medium and long-run to losses in reliable public revenue sources for the state to fund health; where state-owned enterprises provide health coverage to employees, these benefits may be withdrawn post-privatisation, resulting in loss of access to healthcare [73-76]. Fourth, conditionality may be interpreted by donors as firm commitment to reform, rewarded with increases in aid that offset lost revenues for health elsewhere; even so, evidence suggests that aid substitutes-rather than complements-government spending on health, and that aid flows increase for general budget support and debt relief but not for health [22, 77, 78].

Shifting further down the causal chain to the 'social determinants' of health [79], reforms attached to structural adjustment programmes are-fifth-linked to dwindling incomes and increases in unemployment, poverty, and inequality, which are-in turn-root causes of a cascade of health problems over the life-course [6, 80-82]. For instance, wage caps and privatisations can result in job losses, which are linked to increases in alcoholism and suicide in post-communist European countries; exchange rate liberalisation can 
increase food prices, which is tied to deteriorations in children's nutritional status; and the introduction of regressive forms of taxation can reduce poor households' incomes and thus their ability to afford healthcare or lead healthy lives [76, 83-87]. Sixth, education is another key social determinant of health, as it increases individuals' knowledge about health and improves social mobility opportunities which-in turn-affect employment and poverty; yet, studies show IMF and World Bank-mandated user fees for primary education impede educational attainment for children, and that structural adjustment also decrease the protective effect of parents' education on child health [30, 83, 84]. Finally, reforms on environmental policies-typically including deregulation or privatisation of water and sanitation, agriculture, energy, and other natural resources-are linked to environmental degradation, which in-turn affects population health [88-90].

\section{Labour rights}

Several international human rights instruments contain provisions concerning labour rights. The 1966 International Covenant on Civil and Political Rights (ICCPR) articulates the rights to freedom from forced labour and freedom of association, and the ICESCR embodies the right to participate in work and the right to just working conditions. Labour rights are also protected by fundamental conventions of the International Labour Organisation (ILO) and the 1998 ILO Declaration on Fundamental Principles and Rights at Work [91]. In its 2005 General Comment 18 (on the right to work), the UN Committee on Economic, Social, and Cultural Rights understood this as the right of everyone to earn a living by work that is freely chosen, including the right not to be deprived of work unfairly. States are thereby obligated to allocate resources and adopt policies aimed at reducing their unemployment rate [92]. The Committee also stresses that international financial institutions, such as the IMF and World Bank, must pay attention to the protection to the right to work in their lending policies.

The IMF and World Bank have incorporated reforms that directly affect the right to work and to just working conditions via the deregulation of labour markets. Their rationale is based on supply-side economics, which posits that firms invest more when labour markets are flexible and when the costs associated with labour protections are low. For example, an IMF staff report on Romania states, '[L]abor market rigidities are impediments to a business-friendly environment and Romania stands out compared to other countries, particularly on costs of hiring and firing workers' [93]. The IMF and World Bank, thus, view labour market flexibility as a key ingredient for enhancing the global competitiveness of goods and services produced in borrowing countries.

However, critics argue that the IMF and World Bank neglect the human rights implications of reducing labour market rigidities [94-97]. In a recent report on structural adjustment programmes, the UN Human Rights Council concludes that such policies have contravened international human rights obligations by eroding labour rights [6]. A study examining 131 countries for the period 1981 to 2003 also found that the more time a country was implementing structural adjustment programmes, the lower the level of protection of labour rights [94]. Another study on 123 countries found a negative association between structural adjustment programmes and collective labour rights, particularly with regard to workers' freedom of association and the right to collective bargaining both in law and in practice [95]. 
Labour reforms have been a consistent feature of structural adjustment programmes since the mid-1990s [7]. The majority of these are targets related to wage caps and employment limits which have-in turn-impeded the right to work. Indeed, a study of 110 countries found a negative association between IMF programmes and workers' wages, as proxied by the labour share of income in the manufacturing sector [82]. A cross-national study examining the effects of IMF-mandated public sector reforms found that governments cut the public sector wage bill only when this is set out as a required condition; but uncovered evidence of backsliding toward higher expenditure on public sector wages once the programme ended [98]. Similarly, the labour share in relation to GDP declined in recent adjustment programmes in Eurozone countries, especially Greece [99].

With regard to employment limits, Moldova's IMF-designed labour-related reforms included measures to 'optimize the number of employees in the budgetary sector [... by] eliminat[ing] at least 4,000 positions' in 2010 [100]. Recently, restrictions on hiring in the public sector were introduced in Cyprus, Greece, Ireland, and Portugal; and Tunisia's 2014 programme incorporated a salary freeze for civil servants [6]. Studies also link layoffs incorporated in adjustment programmes to declines in unionisation rates (since labour unions are typically more prevalent in the public sector), a weakening of the bargaining power of workers more generally, and an expansion in the informal sector, thereby curtailing the right to decent working conditions [5, 82, 101, 102].

Labour reforms have also featured difficult structural reforms geared towards a fundamental transformation of social security institutions and the deregulation of labour laws. Several studies find that the IMF and World Bank promote labour laws that legalise temporary work contracts, extend probation periods, remove barriers to firing workers, reduce employee entitlements, and dismantle rights to form and join labour unions and to collectively bargain with employees [5, 94, 95, 97, 103, 104]. Emphasising the ubiquity of such measures, research found that almost one-third of letters of intent between the IMF and governments from 1998 to 2005 contained commitments towards flexible labour market regulation [105].

Examples abound. In a request for financial assistance from Morocco in 2011, the IMF emphasised the need for deregulating fixed-term contracts and reducing statutory labour protections [5]. Romania's 2010 IMF programme targeted pensions with a 15\% cut and required parliamentary approval of pension reform legislation, which included further pay-out reductions and raises to the retirement age [7]. The recent IMF programmes in Eurozone countries also incorporated labour-related reforms on deregulation and social security systems. Greece's programme included reforms to the collective bargaining system-giving precedence to firm-level (as opposed to sectoral) agreement$s$ - and measures to reduce minimum wages and employee dismissal costs [3, 7]. Similarly, Portugal's adjustment programme stipulated increases to the retirement age, weakening of collective bargaining, and the introduction of a public administration labour law aimed at aligning the public employment regime to the private sector rules and terminating tenure [7]. Furthermore, most Latin American governments made changes to their laws governing hiring, dismissal, and work hours in the past 20 years as a result of IMF pressure [104].

State-owned enterprise privatisation and pricing reforms can also directly impede the right to work. For the IMF and World Bank, state-owned enterprises are viewed as the 
major source of public deficit that, in turn, underpins many of the economic problems that sees countries turn to these institutions for loans [106]. Consequently, they have called for wide-ranging reforms of state-owned enterprises in order to reduce state aid and limit the deficit on the national budget. These reforms typically undermine labour rights by mandating reductions in entitlements for employees in state-ownedenterprises; they may also affect collective labour rights as collateral damage from the labour force's diminishing bargaining power, given that the sector typically features high levels of collective representation. For example, in an IMF programme dating from 1993, Mongolia agreed to 'establish new procedures of corporate governance' for its state-owned enterprises, '[...] including requirements for fixed-term performance-based management contracts' [107]. In Pakistan, privatisation of state-owned enterprises led to the replacement of stable jobs with precarious jobs involving sub-contractors, which were not fully subject to the labour law provisions [108].

Finally, several reforms can indirectly affect the protection of labour rights. Those related to the trade and exchange system frequently call for the liberalisation of trade, which prompts a race to the bottom in respect of labour rights as domestic producers pressure policy-makers to drive down labour costs in order to withstand global competition [94-96, 101, 109-111]. Furthermore, financial sector reforms that mandate a restrictive monetary policy may convince policy-makers to remove worker entitlements-such as a minimum wage-since higher wage levels tend to be inflationary [96].

\section{Civil and political rights}

The responsibility of the state in respect of civil and political rights is also codified in the ICCPR. Political rights refer to the right to vote, the right to freedom of speech and the press, and the right not to be discriminated against on the basis of ethnicity, gender, sexual orientation, language, religion, social class, or political opinion; civil rights-also known as personal integrity or physical integrity rights-denote the right to be protected from torture, extra-judicial killings, disappearance, or political imprisonment, among others [94]. While there is less research on the civil and political rights consequences of structural adjustment reforms than on health and labour rights, most studies agree that the imposition of these policies exacerbates breaches of these human rights.

Arguments linking structural adjustment programmes to civil and political rights violations are rooted in two causal pathways. First, a direct pathway suggests that the transfer of power from the state to the market on the basis of conditionality can increase rights abuses by weakening the government's ability to enforce such rights [94, 112-116]. The protection of civil rights, for example, requires government expenditures for properly trained and adequately compensated judges, police, and the military and for institutions to monitor the activities of enforcement entities [113]. One study also shows that IMF programmes are linked to deteriorating levels of respect for women's rights because they undermine government ability and willingness to protect such rights [114]. In addition, cross-national studies find evidence that participation in structural adjustment programmes are associated with reductions in aggregated scores on borrowers' levels of democracy [117, 118]. However, recent research contradicts these studies, observing a modest but positive effect of IMF programme participation on 
democracy. The study argues that autocratic regimes have less capacity to repress opposition when under a tighter budget constraint imposed by the IMF, allowing greater levels of political competition to emerge. Another study of 131 developing countries between 1981 and 2003 shows that while structural adjustment programmes led to increased hardship for the poor, greater civil conflict, and more repression of human rights, they are also-paradoxically-associated with some democratic reforms, including freer and fairer elections, greater freedom to form and join organisations, and greater freedom of speech and press [94].

Second, an indirect pathway suggests that the infringement of health and labour rights entailed by conditionality results in a rise of social protest and instability, leading to violent repression by the ruling government that amounts to breaches of civil and political rights. We know of several studies that test for-and support-this aggregate causal relationship [94, 112, 113, 119]. Cross-national empirical studies also support the notion that structural adjustment programmes are associated with increases in social and political instability, including incidents of mass demonstrations, strikes, riots, conflict, and coup d'états [120-124]. Furthermore, structural adjustment programmes are linked to declines in economic growth [117, 125-127], which is-in turn-associated with reduced respect for human rights [94, 128-130]. Case studies also typify the purported pattern of events [94, 131-135]. In Bolivia, limited progress under a 15year stint of successive structural adjustment programmes came to a head in the early2000s, following increases in unemployment and poverty, reductions in real wages, cuts in social expenditures, and-most infamously-the privatisation and subsequent price hikes of the city of Cochabamba's water system [94]. Those most adversely affected responded with a spate of militant anti-government demonstrations and protests, to which the government responded by declaring a state of emergency and increasing its use of force against protestors. In Turkey, social unrest followed an announcement that the democratically elected government had signed an IMF programme in June 1980 and, by September of that year, the military dissolved parliament and suspended civilian political institutions [136].

\section{Conclusions}

In offering loans in exchange for policy reforms, the IMF and World Bank are imbued with substantial policy influence on governments throughout the world. We have shown that since the introduction of structural adjustment in the 1980s, the two organisations have made ongoing attempts to overhaul the underlying institutions of borrowing countries, particularly via stabilisation, liberalisation, deregulation, and privatisation conditions. Our review revealed that conditionality prompts mostly perverse implications for the enjoyment of health, labour, and civil and political rights.

We note some caveats to our review. First, studies do not distinguish between the human rights effects of policy reforms actively sought by borrowing governments for inclusion in their lending arrangements from those unilaterally imposed by IFIs [13]. This gap offers an avenue for future research to pursue. Second, many of the studies deploy quantitative techniques to calculate average treatment effects on data spanning a period of a decade or more. Such a research design implicitly assumes that the impact on human rights is constant throughout the period considered, which may not be an accurate reflection of reality. That being said, there is also evidence of a startling degree 
of similarity in terms of the underlying market-liberalising impetus of structural adjustment across time [7].

While health rights have clear implications for public health, less obvious may be the public health implications of breaches to labour and civil and political rights. Structural adjustment is linked to diminishing labour rights, in turn linked to public health in terms of the extent to which people have access to decent work, a social determinant of health. Those without decent work and working conditions-that is, adequately paid, relatively stable, properly regulated, and with collective representation-typically experience a cascade of detrimental mental and physical health consequences over the life-course [6, 80-82]. So, too, it is the case that civil and political rights act as a (more distant) social determinant of health. Structural adjustment is linked to an increasing likelihood of civil conflict, in turn linked to violent repression which typically results in injury and causalities; unchecked civil conflict can also lead to physical destruction of health facilities, and, in its worst form-such as a full-fledged civil war-the total collapse of a nation's health system $[137,138]$.

Responding to criticism in 2001 that IFIs were ignoring the human rights consequences of their activities, an IMF spokesperson stated that they do not have a mandate to promote human rights and are not 'bound by various human rights declarations and conventions' [139]. Indeed, it appears these organisations try to avoid human rights parlance altogether. According to a speechwriter of the IMF's current Managing Director, Christine Lagarde, 'You cannot put human rights in a speech, [or] it'll be taken out' [140]. Similarly, a United Nations assessment of World Bank policies provocatively concluded that the organisation is 'a human rights-free zone.... It treats human rights more like an infectious disease than universal values and obligations' [141]. But with the highly salient human rights violations in Greece's structural adjustment programmes in recent memory [142], the Committee on Economic, Social and Cultural Rights issued a statement expressing that IFIs are 'bound to comply with human rights ... that are part of customary international law or of the general principles of law, both of which are sources of international law' [143]. Since it is a legal responsibility of the IMF and World Bank to uphold human rights obligations, the question remains as to how the lending practices of these organisations might be revamped in ways that ensure they respect human rights.

Looking forward, the mechanisms identified in this review should serve as a guide for recalibrating structural adjustment programmes in ways that protect and respect existing human rights. In particular, future programmes should be designed with human rights as a core consideration. This entails a shift from managing negative human rights effects caused by conditionality-for instance, via poorly enforced social and priority spending targets-to avoiding policies that pose risks to human rights. As a corollary of this, a human rights impact assessment should be carried out before commencing a programme. It should involve consultation with relevant stakeholders, including public health experts, trade unions, the ILO, and the UN Human Rights Council. Programmes should also be regularly reviewed and evaluated not just in relation to their economic and fiscal targets, but against social policy targets, including reducing unemployment, poverty and social exclusion, and in terms of increased access to affordable healthcare.

In practice, this means an outright rejection of austerity policies, which have gone largely unchallenged despite the historical record of failure in spurring economic 
growth [144]. Indeed, analyses show that government spending in health and social protection not only improves the protection of health rights, but also boosts economic growth [75, 144]. In essence, there is no sound economic logic for the austerity policies pushed by the IMF and World Bank, while austerity represents an immediate threat to global health [145]. But it will also require wide-ranging reforms at the supranational level to ensure struggling governments are vested with the resources necessary to fund a comprehensive social protection system. In this regard, reform of the global taxation system, which currently allows multinational corporations and wealthy individuals to game the system to avoid paying taxes, represents the likeliest source of future revenues for struggling governments [144, 146].

What is clear is that improvements in public health will follow a concerted effort to meet internationally agreed-upon human rights obligations. It is therefore time for IFIs like the IMF and World Bank to take this prescription seriously.

\section{Abbreviations}

ICCPR: International Covenant on Civil and Political Rights; ICESCR: International Covenant on Economic, Social, and Cultural Rights; IFI: International financial institution; ILO: International Labour Organisation; IMF: International Monetary Fund; UN: United Nations

Acknowledgements

Not applicable.

\section{Funding}

The authors gratefully acknowledge funding by the Institute for New Economic Thinking (INET Grant INO13-00020: The Political Economy of Structural Adjustment'), Cambridge Political Economy Society Trust, and the Centre for Business Research at the University of Cambridge.

Availability of data and materials

Not applicable.

\section{Authors' contributions}

TS conducted the literature search and wrote the article. AK contributed to the study's conception and design, and provided extensive revisions. All authors read and approved the final manuscript.

Ethics approval and consent to participate

Not applicable.

\section{Consent for publication}

Not applicable.

Competing interests

The authors declare that they have no competing interests.

\section{Publisher's Note}

Springer Nature remains neutral with regard to jurisdictional claims in published maps and institutional affiliations.

\section{Author details}

${ }^{1}$ Centre for Business Research, University of Cambridge, Cambridge, UK. ${ }^{2}$ Department of Politics \& International Relations, Royal Holloway, University of London, Egham, UK. ${ }^{3}$ Trinity College, University of Oxford, Oxford, UK.

${ }^{4}$ Department of Sociology, University of Amsterdam, Amsterdam, The Netherlands.

Received: 4 September 2017 Accepted: 7 November 2017

Published online: 30 November 2017

References

1. Kentikelenis A, Karanikolos M, Papanicolas I, Basu S, McKee M, Stuckler D. Health effects of financial crisis: omens of a Greek tragedy. Lancet. 2011;378:1457-8.

2. Kentikelenis A, Karanikolos M, Reeves A, McKee M, Stuckler D. Greece's health crisis: from austerity to denialism. Lancet. 2014;383:748-53.

3. Kentikelenis A. The social aftermath of economic disaster: Karl Polanyi, countermovements in action, and the Greek crisis. Socio Econ Rev. 2017;1-21.

4. Karanikolos M, Kentikelenis A. Health inequalities after austerity in Greece. Int J Equity Health. 2016;15:83. 
5. United Nations General Assembly. Report A/HRC/34/57: report of the independent expert on the effects of foreign debt and other related international financial obligations of states on the full enjoyment of all human rights, particularly economic, social and cultural rights. New York; 2016.

6. United Nations General Assembly. Report A/HRC/34/57/Add.1: report of the independent expert on the effects of foreign debt and other related international financial obligations of states on the full enjoyment of all human rights, particularly economic, social and cultural rights. New York; 2016

7. Kentikelenis A, Stubbs T, King L. IMF conditionality and development policy space, 1985-2014. Rev Int Polit Econ. 2016;23:543-82.

8. Babb S, Kentikelenis A. International financial institutions as agents of neoliberalism. In: Cahill D, Cooper M, Konings M, editors. The sage handbook of neoliberalism. Thousand Oaks: Sage; 2018.

9. Kentikelenis A, Seabrooke L. The politics of world polity: script-writing in international organizations. Am Sociol Rev. 2017;82(5):1065-1092.

10. Thomson M, Kentikelenis A, Stubbs T. Structural adjustment programmes adversely affect vulnerable populations: a systematic-narrative review of their effect on child and maternal health. Public Health Rev. 2017;38:13.

11. Cornia GA, Jolly R, Stewart F. Adjustment with a human face: protecting the vulnerable and promoting growth, vol. 1. Oxford: Oxford University Press; 1987.

12. Woods N. The Globalizers: the IMF, the World Bank, and their borrowers. New York: Cornell University Press; 2006.

13. Vreeland J. IMF program compliance: aggregate index versus policy specific research strategies. Rev Int Organ. 2006; $1: 359-78$

14. International Monetary Fund. Articles of agreement. Washington, DC; 2016.

15. Kapur D, Lewis JP, Webb R. The World Bank: its first half century, volume 1: history. Washington, DC: Brookings Institution Press; 1997.

16. Babb S. Behind the development banks: Washington politics, world poverty, and the wealth of nations. Chicago: University of Chicago Press; 2009

17. Babb S, Buira A. Mission creep, mission push and discretion: the case of IMF conditionality. In: Buira A, editor. The IMF and World Bank at sixty. London: Anthem Press; 2005. p. 59-83.

18. Pfeiffer J, Chapman R. Anthropological perspectives on structural adjustment and public health. Annu Rev Anthropol. 2010:39:149-65.

19. Summers LH, Pritchett LH. The structural-adjustment debate. Am Econ Rev. 1993;83:383-9.

20. Williamson J. What Washington means by policy reform. In: Williamson J, editor. Latin American adjustment: how much has happened? Washington. DC: Institute for International Economics; 1990. p. 7-20.

21. Bird G, Rowlands D. Do IMF programmes have a catalytic effect on other international capital flows? Oxford Dev Stud. 2002;30:229-49

22. Stubbs T, Kentikelenis A, King L. Catalyzing aid? The IMF and donor behavior in aid allocation. World Dev 2016;78:511-28

23. Dollar D, Levin V. The increasing selectivity of foreign aid, 1984-2003. World Dev. 2006;34:2034-46.

24. Babb S, Carruthers B. Conditionality: forms, function, and history. Annu Rev Law Soc Sci. 2008:4:13-29.

25. Stiglitz J. Globalization and its discontents. New York: W. W. Norton; 2002.

26. Rodrik D. One economics, many recipies: globalization, institutions, and economic growth. Princeton: Princeton University Press; 2007.

27. International Monetary Fund. Creating policy space - responsive design and streamlined conditionality in recent low-income country programs. Washington, DC; 2009.

28. World Bank. 2009 development policy lending retrospective: flexibility, customization, and results. Washington, DC; 2009.

29. Greer S. Structural adjustment comes to Europe: lessons for the Eurozone from the conditionality debates. Glob Soc Policy. 2014;14:51-71.

30. Kentikelenis A. Structural adjustment and health: a conceptual framework and evidence on pathways. Soc Sci Med. 2017:187:296-305

31. United Nations Committee on Economic, Social and Cultural Rights. General comment no. 14: the right to the highest attainable standard of health (Art. 12). New York; 2000

32. Ooms G, Hammonds R. Global constitutionalism, applied to global health governance: uncovering legitimacy deficits and suggesting remedies. Glob Health. 2016;12:84.

33. Sridhar D. The battle against hunger: choice, circumstance, and the World Bank. Oxford: Oxford University Press; 2008.

34. Gupta S. Response of the International Monetary Fund to its critics. Int J Health Serv. 2010;40:323-6.

35. Gupta S. Can a causal link be drawn? A commentary on "the impact of IMF conditionality on government health expenditure: a cross-national analysis of 16 West African nations". Soc Sci Med. 2017;181:199-201.

36. Gupta S, Dicks-Mireaux L, Khemani R, McDonald C, Verhoeven M. Social issues in IMF-supported programs. DC: Washington; 2000.

37. IMF. Protecting the most vulnerable under IMF-supported programs. IMF factsheet. 2015. http://www.imf.org/ external/np/exr/facts/protect.htm. Accessed 11 May 2015.

38. Kentikelenis A, Stubbs T, King L. Structural adjustment and public spending on health: Evidence from IMF programs in low-income countries. Soc Sci Med. 2015;126:169-76.

39. Nooruddin I, Simmons JW. The politics of hard choices: IMF programs and government spending. Int Organ. 2006;60:1001-33.

40. Noy S. New contexts, different patterns? A comparative analysis of social spending and government health expenditure in Latin America and the OECD. Int J Comp Sociol. 2011;52:215-44.

41. Stubbs T, Kentikelenis A, Stuckler D, McKee M, King L. The impact of IMF conditionality on government health expenditure: a cross-national analysis of 16 West African nations. Soc Sci Med. 2017;174:220-7.

42. Stubbs T, Kentikelenis A, Stuckler D, McKee M, King L. The IMF and government health expenditure: a response to Sanjeev Gupta. Soc Sci Med. 2017;181:202-4.

43. Stubbs T, Kentikelenis A. Targeted social safeguards in the age of universal social protection: the IMF and health systems of low-income countries. Crit Public Health. 2017; 
44. Kentikelenis A, King L, McKee M, Stuckler D. The International Monetary Fund and the Ebola outbreak. Lancet Glob Heal. 2015;3:e69-70.

45. Reeves A, McKee M, Basu S, Stuckler D. The political economy of austerity and healthcare: cross-national analysis of expenditure changes in 27 European nations 1995-2011. Health Policy (New York). 2014;115:1-8.

46. Sridhar D, Woods N. Are there simple conclusions on how to channel health funding? Lancet. 2010;375:1326-8.

47. Stuckler D, King L, Basu S. International monetary fund programs and tuberculosis outcomes in post-communist countries. PLoS Med. 2008:5:1079-90.

48. Anyanwu JC, Erhijakpor AEO. Health expenditures and health outcomes in Africa. Afr Dev Rev. 2009;21:400-33.

49. Palma-Solís MA, Díaz CÁ-D, Franco-Giraldo Á, Hernández-Aguado I, Pérez-Hoyos S. State downsizing as a determinants of infant mortality and achievement of millennium development goal 4. Int J Health Serv. 2009;39: 389-403.

50. Thomson S. Economic crisis, health systems and health in Europe: impact and implications for policy. Maidenhead: Open University Press; 2015.

51. Sen K, Koivusalo M. Health care reforms and developing countries-a critical overview. Int J Health Plann Manag. 1998;13:199-215

52. Akin J, Birdsall N, de Ferranti D. Financing health services in developing countries: an agenda for reform. Washington, DC; 1987

53. De Vogli R, Birbeck GL. Potential impact of adjustment policies on vulnerability of women and children to HIV/ AIDS in sub-Saharan Africa. J Health Popul Nutr. 2005;23:105-20.

54. James C, Morris SS, Keith R, Taylor A. Impact on child mortality of removing user fees: simulation model. Br Med J. 2005:331:747-9.

55. Yates R. Universal health care and the removal of user fees. Lancet. 2009:373:2078-81.

56. Kentikelenis A, Karanikolos M, Williams G, Mladovsky P, King L, Pharris A, et al. How do economic crises affect migrants' risk of infectious disease? A systematic-narrative review. Eur J Pub Health. 2015;25:937-44.

57. Kentikelenis A. Bailouts, austerity and the erosion of health coverage in Southern Europe and Ireland. Eur J Pub Health. 2015:25:365-6.

58. Homedes N, Ugalde A. Why neoliberal health reforms have failed in Latin America. Health Pol (New York). 2005;71:83-96.

59. Kentikelenis A, Shriwise A. International organizations and migrant health in Europe. Public Health Rev. 2016;37:19.

60. Loewenson R. Structural adjustment and health policy in Africa. Int J Health Serv. 1995;23:717-30.

61. Pfeiffer J. International NGOs and primary health care in Mozambique: the need for a new model of collaboration. Soc Sci Med. 2003:56:725-38.

62. Ravindran TKS. Privatisation in reproductive health services in Pakistan: three case studies. Reprod Health Matters. 2010;18:13-24

63. Djibuti M, Rukhadze N, Hotchkiss DR, Eisele TP, Silvestre EA. Health systems barriers to effective use of infectious disease surveillance data in the context of decentralization in Georgia: a qualitative study. Health Policy (New York). 2007;83:323-31.

64. Marphatia A. The adverse effects of International Monetary Fund programs on the health and education workforce. Int J Health Serv. 2010;40:165-78.

65. Marphatia AA, Moussié R, Ainger A-M, Archer D. Confronting the contradictions: the IMF, wage bill caps and the case for teachers. Johannesburg; 2007.

66. Stuckler D, Basu S. The International Monetary Fund's effects on global health: before and after the 2008 financial crisis. Int J Health Serv. 2009:39:771-81.

67. Kawewe SM, Dibie R. The impact of economic structural adjustment programs [ESAPs] on women and children: implications for social welfare in Zimbabwe. J Sociol Soc Welf. 2000;27:79-107.

68. McColl K. Fighting the brain drain. Br Med J. 2008;337:958-61.

69. Gupta S. Response to "the International Monetary Fund and the Ebola outbreak". Lancet Glob Heal. 2015;3:e78.

70. van der Gaag J, Barham T. Health and health expenditures in adjusting and non-adjusting countries. Soc Sci Med. 1998:46:995-1009.

71. Clements B, Gupta S, Nozaki M. What happens to social spending in IMF-supported programmes? Appl Econ. 2013:48:4022-33.

72. Crivelli E, Gupta S. Does conditionality in IMF-supported programs promote revenue reform?. Int tax public Financ. 2016:23(3):550-579.

73. King L, Hamm P, Stuckler D. Rapid large-scale privatization and death rates in ex-communist countries: an analysis of stress-related and health system mechanisms. Int J Health Serv. 2009;39:461-89.

74. Peabody JW. Economic reform and health sector policy: lessons from structural adjustment programs. Soc Sci Med. 1996:43:823-35

75. Stuckler D, Basu S. The body economic: why austerity kills. New York: Basic Books: 2013.

76. Stuckler D, King L, McKee M. Mass privatisation and the post-communist mortality crisis: a cross-national analysis. Lancet. 2009:373:399-407.

77. Lu C, Schneider M, Gubbins P, Leach-Kemon K, Jamison D, Murray C. Public financing of health in developing countries: a cross-national systematic analysis. Lancet. 2010;375:1375-87.

78. Stuckler D, Basu S, McKee M. International Monetary Fund and aid displacement. Int J Health Serv. 2011;41:67-76.

79. Marmot M. Health in an unequal world. Lancet. 2006;368:2081-94.

80. Oberdabernig D. Revisiting the effects of IMF programs on poverty and inequality. World Dev. 2013:46:113-42.

81. Pickett KE, Wilkinson RG. Income inequality and health: a causal review. Soc Sci Med. 2015;128:316-26.

82. Vreeland J. The effect of IMF programs on labor. World Dev. 2002;30:121-39.

83. Babb S. The social consequences of structural adjustment: recent evidence and current debates. Annu Rev Sociol. 2005:31:199-222.

84. Daoud A, Nosrati E, Reinsberg B, Kentikelenis A, Stubbs TH, King LP. Impact of International Monetary Fund programs on child health. Proc Natl Acad Sci. 2017;114:6492-7.

85. Handa S, King D. Adjustment with a human race? Evidence from Jamaica. World Dev. 2003;31:1125-45 
86. Stewart F. The many faces of adjustment. World Dev. 1991;19:1847-64.

87. Stuckler D, Basu S, Suhrcke M, Coutts A, McKee M. The public health effect of economic crises and alternative policy responses in Europe: an empirical analysis. Lancet. 2009;374:315-23.

88. Pacheco P. Agricultural expansion and deforestation in lowland Bolivia: the import substitution versus the structural adjustment model. Land Use Policy. 2006;23:205-25.

89. Shandra CL, Shandra JM, London B. World Bank structural adjustment, water, and sanitation: a cross-national analysis of child mortality in sub-Saharan Africa. Organ Environ. 2011;24:107-29.

90. Shandra J, Shor E, London B. Debt, structural adjustment, and organic water pollution. Organ Environ. 2008;21:38-55.

91. International Labour Organization. ILO declaration on fundamental principles and rights at work and its follow-up. Geneva; 2010.

92. United Nations Committee on Economic, Social and Cultural Rights. General comment no. 18: the right to work. New York; 2005.

93. International Monetary Fund. Romania: staff report for the 2006 article IV consultation. Country report no. 06/168. Washington, DC; 2006

94. Abouharb MR, Cingranelli DL. Human rights and structural adjustment. Cambridge: Cambridge University Press; 2007.

95. Blanton RG, Blanton SL, Peksen D. The impact of IMF and World Bank programs on labor rights. Polit Res Q. 2015; 68:324-36.

96. Blanton RG, Peksen D. Economic liberalisation, market institutions and labour rights. Eur J Polit Res. 2016;55:474-91.

97. Caraway T, Rickard S, Anner M. International negotiations and domestic politics: the case of IMF labor market conditionality. Int Organ. 2012;66:27-61.

98. Rickard S, Caraway T. The international politics of austerity: the puzzling case of public sector reforms. London; 2013.

99. George M, Dimitrios K, Stergios A. The economic crisis (2008) and effects on income. The case of Greece. Procedia Econ Financ. 2015;19:27-36.

100. International Monetary Fund. Republic of Moldova: letter of intent, memorandum of economic and financial policies, and technical memorandum of understanding. Washington, DC; 2010.

101. Martin N, Brady D. Workers of the less developed world unite? A multilevel analysis of unionization in less developed countries. Am Sociol Rev. 2007;72:562-84.

102. Roberts K. Social inequalities without class cleavages in Latin America's neoliberal era. Stud Comp Int Dev. 2002; 36:3-33.

103. Bakvis P. The World Bank's doing business report: a last fling for the Washington consensus? Transf Eur Rev Labour Res. 2009;15:419-38.

104. Burgess K. Global pressures, national policies, and labor rights in Latin America. Stud Comp Int Dev. 2010;45:198-224.

105. Anner M, Caraway T. International institutions and workers' rights: between labor standards and market flexibility. Stud Comp Int Dev. 2010:45:151-69.

106. Waterbury J. The heart of the matter? Public enterprise and the adjustment process. In: Haggard S, Kaufman R, editors. The politics of economic adjustment: international constraints, distributive conflicts and the state. Princeton: Princeton University Press; 1992. p. 182-220.

107. International Monetary Fund. Mongolia: staff report for the 1993 article IV consultation and request for arrangements under the enhanced structural adjustment facility. EBS/93/79. Washington, DC; 1993.

108. Munir KA, Naqvi N, Usmani A. The abject condition of labor in Pakistan. Int Labor Work Hist. 2015;87:174-83.

109. Blanton RG, Blanton SL, Peksen D. Financial crises and labor: does tight money loosen labor rights? World Dev. 2015;76:1-12.

110. Mosley L, Uno S. Racing to the bottom or climbing to the top? Economic globalization and collective labor rights. Comp Polit Stud. 2007;40:923-48.

111. Rudra N. Globalization and the race to the bottom in developing countries: who really gets hurt? Cambridge: Cambridge University Press; 2008.

112. Abouharb MR, Cingranelli DL. The human rights effects of World Bank structural adjustment, 1981-2000. Int Stud Q. 2006;50:233-62.

113. Abouharb MR, Cingranelli DL. IMF programs and human rights, 1981-2003. Rev Int Organ. 2009;4:47-72.

114. Detraz N, Peksen D. The effect of IMF programs on women's economic and political rights. Int Interact. 2016:42:81-105.

115. Donnelly J. Universal human rights in theory and practice. 3rd ed. Ithaca: Cornell University Press; 2013.

116. Englehart NA. State capacity, state failure, and human rights. J Peace Res. 2009;46:163-80.

117. Barro R, Lee J-W. IMF programs: who is chosen and what are the effects? J Monet Econ. 2005;52:1245-69.

118. Brown C. Democracy's friend or foe? The effects of recent IMF conditional lending in Latin America. Int Polit Sci Rev. 2009;30:431-57.

119. Franklin J. IMF conditionality, threat perception, and political repression: a cross-national analysis. Comp Polit Stud. 1997;30:576-606.

120. Auvinen JY. IMF intervention and political protest in the third world: a conventional wisdom refined. Third World Q. 1996;17:377-400.

121. Casper BA. IMF programs and the risk of a coup d'etat. J Confl Resolut. 2017;61:964-96.

122. Dreher A, Gassebner M. Do IMF and World Bank programs induce government crises? An empirical analysis. Int Organ. 2012;66:329-58.

123. Hartzell CA, Hoddie M, Bauer M. Economic liberalization via IMF structural adjustment: sowing the seeds of civil war? Int Organ. 2010;64:339-56.

124. Walton J, Ragin C. Global and national sources of political protest: third world responses to the debt crisis. Am Sociol Rev. 1990;55:876-90.

125. Dreher A. IMF and economic growth: the effects of programs, loans, and compliance with conditionality. World Dev. 2006;34:769-88.

126. Przeworski A, Vreeland J. The effect of IMF programs on economic growth. J Dev Econ. 2000;62:385-421.

127. Vreeland J. The IMF and economic development. Cambridge: Cambridge University Press; 2003. 
128. Davenport C, Armstrong DA. Democracy and the violation of human rights: a statistical analysis from 1976 to 1996. Am J Pol Sci. 2004;48:538-54.

129. Poe SC, Tate CN. Repression of human rights to personal integrity in the 1980s: a global analysis. Am Polit Sci Rev. 1994:88:853-72.

130. Poe SC, Tate CN, Keith LC. Repression of the human right to personal integrity revisited: a global cross-national study covering the years 1976-1993. Int Stud Q. 1999;43:291-313.

131. Andersen R. How multilateral development assistance triggered the conflict in Rwanda. Third World Q. 2000;21:441-56.

132. Auyero J. Glocal riots. Int Sociol. 2001;16:33-53.

133. Morrisson C, Lafay J-D, Dessus S. The political conditions of adjustment in Africa 1980-90. In: van der Hoeven R, van der Kraaij F, editors. Structural adjustment and beyond in sub-Saharan Africa: research and policy issues. London: Heinemann; 1994. p. 126-48.

134. Storey A. Economics and ethnic conflict: structural adjustment in Rwanda. Dev Policy Rev. 1999;17:43-63.

135. Walton J, Seddon D. Free markets and food riots: the politics of global adjustment. Cambridge, Massachusetts: Blackwell; 1994.

136. Nelson S, GPR W. Are IMF lending programs good or bad for democracy? Rev Int Organ. 2016:1-36.

137. Benton A, Dionne KY. International political economy and the 2014 West African Ebola outbreak. Afr Stud Rev. 2015:58:223-36.

138. Binagwaho A, Farmer P, Nsanzimana S, Karema C, Gasana M, de Dieu NJ, et al. Rwanda 20 years on: investing in life. Lancet. 2014;383:1-5.

139. Capdevila G. IMF not taking into account human rights issues. Global Policy Forum. 2017;39:392-416. https:// www.globalpolicy.org/component/content/article/209/42944.html. Accessed 1 Jul 2017

140. Reinold T. The path of least resistance: mainstreaming "social issues" in the International Monetary Fund. Glob Soc; 2016.

141. United Nationa General Assembly. Report A/70/274: extreme poverty and human rights. New York; 2015.

142. de Schutter O, Dermine P. The two constitutions of Europe: integrating social rights in the new economic architecture of the union. Louvain-la-Neuve; 2016.

143. United Nations Committee on Economic, Social and Cultural Rights. Public debt, austerity measures and the international covenant on economic, social and cultural rights. New York; 2016.

144. Labonté R, Stuckler D. The rise of neoliberalism: how bad economics imperils health and what to do about it. J Epidemiol Community Health. 2016;70:312-8.

145. Ruckert A, Labonté R. The financial crisis and global health: the International Monetary Fund's (IMF) policy response. Health Promot Int. 2013;28:357-66.

146. Ruckert A, Labonté R. Health inequities in the age of austerity: the need for social protection policies. Soc Sci Med. 2017;187:306-11.

\section{Submit your next manuscript to BioMed Central and we will help you at every step:}

- We accept pre-submission inquiries

- Our selector tool helps you to find the most relevant journal

- We provide round the clock customer support

- Convenient online submission

- Thorough peer review

- Inclusion in PubMed and all major indexing services

- Maximum visibility for your research

Submit your manuscript at www.biomedcentral.com/submit 